\title{
Imperial Agendas, Global Solidarities, and Third World Socio-Legal Studies: Methodological Reflections
}

Radha D'Souza

Follow this and additional works at: http://digitalcommons.osgoode.yorku.ca/ohlj

Part of the Law and Society Commons

Article

\section{Citation Information}

D'Souza, Radha. "Imperial Agendas, Global Solidarities, and Third World Socio-Legal Studies: Methodological Reflections." Osgoode Hall Law Journal 49.3 (2012) : 409-444.

http://digitalcommons.osgoode.yorku.ca/ohlj/vol49/iss3/1 


\title{
Imperial Agendas, Global Solidarities, and Third World Socio-Legal Studies: Methodological Reflections
}

\begin{abstract}
This article interrogates the methodological lenses through which law in the Third World is commonly analyzed in socio-legal studies. Third World socio-legal studies, this article argues, is a field in search of philosophical foundations. It continues to rely on conceptual categories and analytical frameworks developed through the intellectual, cultural, and social histories of Western capitalist societies, which it extends uncritically to different intersubjective orders in Third World contexts. The article examines the common grounds shared by two apparently competing discourses about law in the Third World, which I label imperial agendas and global solidarities. It is difficult to speak about the Third World without becoming mired in conceptual contradictions. One reason for the methodological problems in Third World socio-legal studies is that social philosophy, and liberal philosophy in particular, undermines the concept of society. This article begins by examining the meaning of society in social philosophy. It then interrogates three dichotomous sets of analytical frameworks that are often invoked in Third World socio-legal studies: (a] comparative law versus Third World Approaches to International Law (TWAILI; (b) economic or modern law versus cultural or traditional law; and (c) state centralism versus legal pluralism. The article argues for a differentiated understanding of society at the ontological, structural, and empirical levels, which should help transcend binary approaches and facilitate theoretical reflections about the Third World without subsuming its specificities. The article concludes by arguing for a sustained research program to put Third World Socio-legal Studies on firm methodological foundations.
\end{abstract}

Keywords

Sociological jurisprudence; Law--Social aspects--Developing countries 


\title{
Imperial Agendas, Global Solidarities, and Third World Socio-legal Studies: Methodological Reflections
}

\author{
RADHA D'SOUZA*
}

\begin{abstract}
This article interrogates the methodological lenses through which law in the Third World is commonly analyzed in socio-legal studies. Third World socio-legal studies, this article argues, is a field in search of philosophical foundations. It continues to rely on conceptual categories and analytical frameworks developed through the intellectual, cultural, and social histories of Western capitalist societies, which it extends uncritically to different intersubjective orders in Third World contexts. The article examines the common grounds shared by two apparently competing discourses about law in the Third World, which I label imperial agendas and global solidarities. It is difficult to speak about the Third World without becoming mired in conceptual contradictions. One reason for the methodological problems in Third World socio-legal studies is that social philosophy, and liberal philosophy in particular, undermines the concept of society. This article begins by examining the meaning of society in social philosophy. It then interrogates three dichotomous sets of analytical frameworks that are often invoked in Third World socio-legal studies: (a) comparative law versus Third World Approaches to International Law (TWAIL); (b) economic or modern law versus cultural or traditional law; and (c) state centralism versus legal pluralism. The article argues for a differentiated understanding of society at the ontological, structural, and empirical levels, which should help transcend binary approaches and facilitate theoretical reflections about the Third World without subsuming its specificities. The article concludes by arguing for a sustained research program to put Third World Socio-legal Studies on firm methodological foundations.
\end{abstract}

Cet article tente de comprendre la lorgnette méthodologique à travers laquelle les études socio-juridiques analysent habituellement le droit du Tiers-Monde. Selon l'article, les études socio-juridiques du Tiers-Monde constituent un domaine en quête de fondements philosophiques. Elles continuent de s'appuyer sur des catégories conceptuelles et des structures analytiques découlant du patrimoine intellectuel, culturel et social des sociétés capitalistes occidentales, qu'elles appliquent sans discernement à divers rapports intersubjectifs dans des contextes tiers-mondistes. L'article examine les assises partagées par deux

* School of Law, University of Westminster. I wish to thank the three anonymous reviewers for their valuable feedback. Their input has been used to improve the original draft. 
discours apparemment contradictoires traitant du droit tiers-mondiste, que je qualifierais de visées impérialistes d'une part et de solidarité mondiale d'autre part. Il est difficile de s'entretenirdu Tiers-Monde sans s'enliser dans une mer de contradictions conceptuelles. L'une des raisons qui sous-tendent les problèmes méthodologiques des études sociojuridiques du Tiers-Monde est le fait que la philosophie sociale-et plus particulièrement la philosophie libérale- ébranle le concept-même de société. L'article commence par analyser la signification du concept de société en philosophie sociale. Il examine ensuite trois ensembles dichotomiques de structures analytiques qu'invoquent souvent les études socio-juridiques du Tiers-Monde : a) le droit comparé par rapport aux théories tiers-mondistes du droit international (TWAIL], b] le droit moderne fondé sur l'économie par rapport au droit traditionnel fondé sur la culture et cl le centralisme d'état par rapport au pluralisme juridique. L'article milite en faveur d'une interprétation différenciée de la société sur les plans ontologique, structurel et empirique, qui devrait permettre de transcender les approches dichotomiques et faciliter les réflexion théoriques sur le Tiers-Monde sans faire abstraction de ses particularités. Il propose pour terminer la création d'un programme continu de recherche destiné à doter de solides fondments méthodologiques les études socio-juridiques du Tiers-Monde.

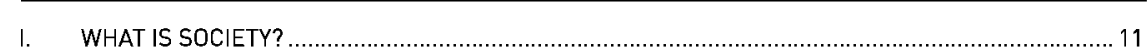

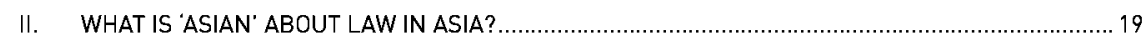

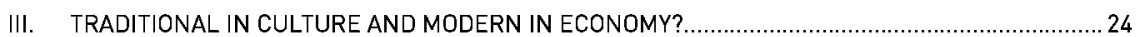

IV. LEGAL PLURALISM, CENTRALISM, AND THIRD WORLD SOCIETIES ......................................... 31

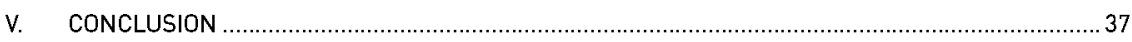

THIRD WORLD SOCIO-LEGAL STUDIES (TWSLS) is a field of study in search of philosophical foundations. ' This is so notwithstanding the large body of scholarship - comprising both dominant and critical pieces - on different aspects of the operation of law in Third World societies. Necessarily generalizing, scholarship on law and colonialism and on law and development in various academic disciplines highlights the temporal and spatial dimensions of law in Third World societies. ${ }^{2}$ More recently, the emphasis on governance in international

1. I use the term in the broadest possible sense as a field of study that examines law in Third World societies and includes sociological, historical, and anthropological approaches as well as policy studies and impact analysis. For distinctions between socio-legal studies and sociology of law and the use of these terms in the United States, Canada, and United Kingdom, see Joan Brockman, "The Impact of Institutional Structures and Power on Law and Society: Is It Time for Reawakening?" (2003) 37 Law \& Soc'y Rev 283.

2. For a review of literature on law and colonialism, see Sally Engle Merry, "Law and Colonialism" (1991) 25 Law \& Soc'y Rev 889 [Engle Merry, "Law and Colonialism"]; Sally Engle Merry, "Colonial Law and Its Uncertainties" (2010) 28 L.HR 1067 [Engle Merry, "Uncertainties"]. For a brief overview of the themes in law and development, see John Hatchard \& Amanda Perry-Kessaris, eds, Law and Development: Facing Complexity in the 21st Century (London: Cavendish, 2003). For an overview of sociological approaches to 
organizations such as the World Bank has produced a critique of international law and international relations from the perspective of global justice. ${ }^{3}$ This impressive body of scholarship has not, however, produced new innovations in conceptual categories in social philosophy. It remains by and large a descriptive and discursive account of law in Third World societies. Analytical frameworks and conceptual categories provide the prisms through which law in societies is understood. Categories that emphasize structuring mechanisms like class, capital, state, and political economy or subject formation like identity, gender, race, and culture remain, by and large, products of Greco-Roman-Christian intellectual traditions that have evolved through the experiences of Euro-American capitalist societies. TWSLS demands much more than sociological attention to contexts. It challenges us to think about the intersubjectivity of the social contexts, i.e., the cognitive mappings embedded in language and culture, that are constitutive of different civilisations or what Jürgen Habermas refers to as "lifeworlds." 4 To put it differently, the development of theory and philosophy continues to borrow, modify, extend, advance, develop, and adapt various concepts and methods from different philosophical strands in the Greco-Roman-Christian intellectual traditions, and the Third World societies provide the historical facts or the social data that differentiate the context for the operation of law. If, as critical legal scholars rightly argue, ${ }^{5}$ the conceptual categories and analytical methods of law

international law, see Sally Engle Merry, "International Law and Sociolegal Scholarship: Toward a Spatial Global Legal Pluralism" (2008) 41 Stud Law, Politics \& Soc'y 149. For a range of approaches to TWSLS and globalization, sce the special issue of the Harvard International Law Journal Symposium, "Comparative Visions of Global Public Order" (2005) 46 Harv Int'1 LJ 388. On the disciplinary scope of sociology of transnational law, see Lawrence M Friedman, "Borders: On the Emerging Sociology of Transnational Law" (1996) 32 Stan J Int'l L 65. For methodological issues in sociolegal studies generally, see Christine B Harrington \& Barbara Yngvesson, "Interpretative Sociolegal Research" (1990) 15 Law \& Soc Inquiry 135.

3. See e.g. Philip Alston, "Ships Passing in the Night: The Current State of Human Rights and Development Debate Seen through the Lens of the Millennium Development Goals" (2005) 27 Hum Rts Q 755; David P Fidler, "A Kinder, Gentler System of Capitulations? International Law, Structural Adjustment Policies, and the Standard of Liberal Globalized Civilization" (2000) 35 Tex Int'l LJ 387; Lucy Williams, ed, International Poverty Law: An Emerging Discourse (London: Zed Books, 2006). See also the works referenced in ibid.

4. Jürgen Habermas, The theory of communicative action: Reason and the Rationalization of Society, vol 1, translated by Thomas McCarthy (Cambridge, UK: Polity Press, 1989); Jürgen Habermas, The theory of communicative action: Lifeworld and System: A Critique of Functionalist Reason, vol 2, translated by Thomas McCarthy (Cambridge, UK: Polity Press, 1989).

5. For a review of literature see Engle Merry, "Law and Colonialism," supra note 2; for historical aspects see Diane Krikby \& Catherine Coleborne, eds, Law, history, colonialism: The Reach of the Empire (Manchester, NY: Manchester University Press, 2001); for conceptual aspects see 
have a profound role in colonialism and the inequities of development in Third World societies, should those categories and methods not be called into question? And how can we call them into question without, on the one hand, subsuming the differences between First and Third World societies, as meta-theories with their universal categories and methods tend to do, or on the other hand, undermining the possibility of theory, as postmodern postcolonial emphasis of difference and pluralism tends to do?

One reason why critical understandings of law in Third World societies have not pushed the boundaries of concept formation and theory development is the opacity of the meaning of "society" in contemporary social philosophy. Consequently, the epistemological premise of TWSLS rests on a fault line between philosophical understandings of society, on one hand, and the law that has operated in Third World societies since the advent of colonialism, on the other. This rupture is not adequately captured in TWSLS. Nor are the methodological ramifications of the disjuncture between intersubjective orders and geo-historical realities adequately theorized in TWSLS. If concepts are socially produced in response to geo-historical developments, then it must be acknowledged, in principle at least, that transposing conceptual categories developed in one geo-historical context to another - a method entailed in the universal application of theory-poses methodological questions for TWSLS. Conversely, emphasizing the effects of modern law on Third World societies without adequately understanding the intersubjective, geo-historical, and sociological sources of those effects obfuscates the theory and concepts implicit in those accounts. The epistemological gaps in TWSLS that follow from the fault line mirror a wider problem in social theory. Social philosophy since the Enlightenment and Modernity has conflated the ontological, epistemological, sociological, and empirical meanings of society, as elaborated in Part I below. ${ }^{6}$ Equally, the singular influence of Greco-RomanChristian intellectual traditions has meant that social philosophy is dominated by dualist methods and binary categories that lock theory and practice in adversarial positions.

The epistemological gaps have created paradoxes for TWSLS. Ex-facie dominant TWSLS advances imperial agendas and critical TWSLS advances global solidarities.

Bernard S Cohn, Colonialism and Its Forms of Knowledge: The British in India (Delhi: Oxford University Press, 1997).

6. For an historical understanding of Modernity, see JPS Uberoi, The European Modernity: Science, Truth and Method (New Delhi: Oxford University Press, 2002) at ch 2; for the distinction between Modernity and Enlightenment, see Javeed Alam, "Modernity and Its Philosophic Visions" in KN Panikkar, TV Byres \& Utsa Patnaik, eds, The Making of History: Essays Presented to Irfan Habib (New Delhi: Tulika, 2000) 405. 
In philosophical terms, dominant TWSLS and critical TWSLS appear as mirror images of each other in that they share common theoretical grounds but proceed from different vantage points. The development of TWSLS remains thwarted by binary concepts and frameworks. Popular binaries in TWSLS include modern versus traditional or customary law, economics versus culture, and legal centralism versus pluralism. The binary lenses through which law in Third World societies is studied are effective insofar as they help to deconstruct the operation of law. Beyond that, TWSLS is trapped in conceptual and political conundrums. The resulting deadlock is particularly problematic for global solidarity movements that are motivated by the desire to overcome the impasse of Eurocentrism in theory and promote law as a transformative tool for global justice in the widest possible sense.

In the Parts that follow, these issues are examined at greater length. Part I locates the epistemological gaps in TWSLS in the opacity of the meaning of society in social theory generally. The opacity of the concept of society makes articulation of the differences between First and Third World societies possible only in dualist, often adversarial ways and in binary terms. Using the meaning of society in social philosophy as the point of departure highlights theoretical and methodological problems in TWSLS that follow from that opacity. Parts II, III, and IV unpack three binary sets of analytical frameworks popular in TWSLS, each set made up of a dominant and a critical approach: (a) comparative law versus Third World Approaches to International Law (TWAIL); (b) economic or modern law versus cultural or traditional law; and (c) legal centralism versus legal pluralism.

Part II examines comparative law, which is the dominant framework for TWSLS, by interrogating the idea of Asian law and juxtaposing the comparative law approach with TWAIL — a movement committed to promoting Third World perspectives in international law. Part III widens the scope of the comparative law/TWAIL approaches to examine the divide between economics and culture in TWSLS-a dichotomy closely related to the first but with longer and more enduring roots in colonial history. I use the public/private divide in law to interrogate the ways in which the use of legal concepts sustain specific types of relations between economies and cultures that have come to characterise Third World societies. I argue that there are asymmetries in the language of law and its meanings in particular social contexts, in the substance and form of law, in the abstract legal concepts, and in the historical contexts in which they were introduced and evolved in Third World societies. 
Part IV interrogates the underpinnings of the economic/cultural divide in TWSLS by examining legal centralism and legal pluralism, two popular frameworks of analysis in dominant and critical TWSLS respectively, and by evaluating them against the specific attributes of societies constituted through processes of imperialism or colonialism. In the concluding Part, I return to the importance of problematizing society as a core concept in social theory in order to transcend binary frameworks. The methodological questions discussed in this article are deeply embedded in TWSLS scholarship. The aim of this article is to open up entrenched approaches for wider engagement and to advocate for a research program that will place TWSLS on firmer philosophical and theoretical foundations.

\section{WHAT IS SOCIETY?}

There is considerable semantic confusion in the social sciences and humanities on the appropriate vocabulary to characterize societies with histories of imperial rule. Binary terms like First World and Third World, North and South, developed and underdeveloped, colonial and neo-colonial (or postcolonial), and West and East are often used to describe societies but are widely contested from different theoretical, ideological, and disciplinary perspectives. While most people understand what is being referred to when such terms are used, the conceptual underpinnings of the terms are often imprecise and inaequate to identify appropriate criteria for classifying these types of societies. ${ }^{7}$ Is it possible that the semantic confusion is due to the opaque meaning of society in social theory?

7. The continued use of the term 'Third World' has been called into question. See e.g. Arif Dirlik, "Spectres of the Third World: Global Modernity and the End of the Three Worlds" (2004) 25 Third World Q 131. The term is also defended, inter alia, on the grounds that it is still a useful term. See e.g. Obiora Chinedu Okafor, "Newness, Imperialism, and International Legal Reform in Our Time: A TWAIL Perspective" (2005) 43 Osgoode Hall LJ 171. Mark Berger asserts that there are historical associations with the term that are important. See e.g. Mark T Berger, "After the Third World? History, Destiny and the Fate of Third Worldism" (2004) 25 Third World Q 9. In addition to these reasons, I use the term Third World for a third, more important reason. The historical factors that led to the creation of the 'three worlds' - capitalist (first world), socialist (second world), and (semi)colonial (third world) — and that formed the structural feature of the post-World War II world order continue to inform the historical, structural, political, economic, and cultural realities of those societies. These features remain even after 'Third Worldism' as a solidarity movement of newly independent countries has stalled and the formal architecture of the world order appears to be subsumed by 'globalization.' Throughout this article the term 'First World' is used to denote European societies that were internally reconstituted through the processes of capitalism and informed by corresponding intellectual developments spearheaded by the European Enlightenment. 
Tom Bottomore's A Dictionary of Marxist Thought ${ }^{8}$ defines three uses of the word society: as socialized human beings, as typologies of social formations, and as specific societies. What is important is not to reduce the concept of society to one of these three definitions, but rather to treat all three uses as true and ask ourselves, "What must be the nature of society if all three definitions are true?" Methodologically, such an approach borrows from the non-dualist Jaina traditions of Anekantavada or the philosophy of non-one-sidedness. ${ }^{9}$ Anekantavada methods urge us not to frame questions in the "either this is true or it is false" format, but rather to ask, "If A believes this to be true, and B believes it to be false, what must be the nature of reality that invites both beliefs?"

The methodological approach in Anekantavada presupposes an ontological conception of the nature of Reality that informs epistemological inquiries. In this article, "Reality" (with initial capital) denotes the ontological meaning of the term in the philosophical and cosmological sense that there is a Reality beyond individual spatio-temporal lives, while "reality" (all lower case) denotes the ordinary use of the term to refer to objective existence beyond subjective perceptions as when we speak of social, political, or economic realities. In the Jaina conception, Reality is infinite and irreducible. ${ }^{10}$ In the Buddhist conceptions, Reality is interdependent, contingent and non-essential. ${ }^{11}$ The role of epistemology is to uncover layers of Reality and real relations, metaphorically like peeling an onion. Liberal theory, to the contrary, is based on what Roy Bhaskar calls a "monovalent" ${ }^{12}$ ontology, where the world is reducible, unchanging, and undifferentiated. Bottomore's three uses of "society" may be seen as three levels of meaning, each of which is represented in this article by a different typographical convention: at the ontological level, where human beings are socialized beings and human life is contingent on Society; at the structural level, where Society refers to typologies of geo-historical social formations constituted by a variety of mechanisms (such as capitalism, imperialism, feudalism, or mercantilism); and at the empirical level, where society (usually presented in the plural)refers to specific conjunctures of diverse social, economic, historical, political, and cultural factors and the roles of individuals and groups that characterize specific societies at a given point in time.

8. (Cambridge: Harvard University Press, 1983) at 448-50.

9. For a range of perspectives on the method of Anekantavada, see Nagin J Shah, ed, Jaina Theory of Multiple Facets of Reality and Truth (Anekantavada) (Delhi: Motilal Banarsidass, 2000).

10. Ibid.

11. David J Kalupahana, Nagarjuna: Philosophy of the Middle Way (Albany: University of New York Press, 1986).

12. The Possibility of Naturalism: A Philosophical Critique of the Contemporary Human Sciences (New Jersey: Humanities Press, 1979). 
In this article, therefore, Society denotes the ontological level of meaning, Society the structural, and society or societies the third, empirical level.

Taking philosophy of science as his point of departure, Roy Bhaskar argues that Nature, Society, and "Human Life" (individuals and groups) are ontologically distinct in that they possess different ontological attributes and properties, but that they are nevertheless related. ${ }^{13}$ Society is unilaterally contingent on Nature but the converse is not true in that Nature can exist without Society (as on Mars, for example). Society, as social structures, Bhaskar argues, is always geo-historically produced and involves language, concepts, laws, institutions, technology, norms, and ideologies. The ontological property of human life is its psychological and aesthetic dimension, a property of being human. It gives human beings agency and the capacity to change societies at the empirical level in the short term. Human Life is contingent on Society in that everyone is born into some type of social structure without which life is not possible; yet human agency can transform Society at the structural level in the long term. Society thus has dual ontological properties: It is the condition of Human Life, in Bhaskar's terms, and at the same time can be transformed by it. Human Life is concept-dependent and impelled by the desire to be free from the constraints imposed by social structures. Human beings must therefore always rethink philosophy and theory for transformative action. Bhaskar's pluralist ontology makes it possible to develop a non-dualist epistemology that can provide a coherent account of natural, social, and aesthetic life. It allows for the possibility of theory without subsuming difference.

At the ontological level, it is possible to argue that Society is the structured relationship of Nature and Human Life; it is the ontological median between the two, as it were. The ontological attributes of Society make it possible to postulate different types of societies that are specific geo-historical conjunctures of natures and peoples - in other words, social structures formed through geo-historical processes. The social structures including law, institutions, norms, and cultures, for example, constrain and enable those living within those structures in different ways. At the human level of individuals and groups, transformative action and solidarities become possible if and only if knowledge is driven by empirical realities, takes into account structural causes, and is foregrounded in ontological awareness, i.e., in awareness of one's philosophical world view about the nature of Reality grounded in conceptions of cosmology and ontology. ${ }^{14}$

13. Roy Bhaskar Reclaiming Reality: A Critical Introduction to Contemporary Philosophy (London: Verso, 1989) at 76-83.

14. For a discussion of activism and ontology, see Radha D'Souza, "What Can Activist Scholars Learn from Rumi?" 64 Philosophy East and West [forthcoming in 2014]. 
Liberal philosophy, which continues to be the dominant philosophy in law and social theory, is dismissive of the concept of Society. Society, following William Outhwaite, ${ }^{15}$ is not an empirical concept; it is a theoretical concept. Without conceptualizing Society theoretically, liberal philosophy leaves us with empirical expositions that make theoretical assumptions about the meaning of Society.

Raymond Williams traces the history of the word from meaning "companionship" in the fourteenth century to greater levels of abstractions to mean "associations" and "groups" by the seventeenth century. ${ }^{16}$ The conflicts of the seventeenth century introduced a distinction between Society and state, "... the former an association of free men, drawing on all the early active senses; the latter an organization of power, drawing on all the senses of hierarchy and majesty."17

Thus, there was a divergence between companionship and associations or organizations. By the eighteenth century the transition was decisive. Society was that to which we all belong - a system of social life-and the state was the apparatus of power. By the nineteenth century, Society became an object related to 'man' and the 'individual' but was not the same thing. This paved the way for social systems and the study of 'the social.' The meaning of Society changed with the transformations in capitalism in a European context. The Enlightenment, as a broad intellectual movement, was instrumental in reconceptualizing the meaning of Society in the wake of capitalism and Modernity. ${ }^{18}$

The Enlightenment as an intellectual movement grew in response to European feudalism and responded to the problems of European societies by drawing its conceptual and intellectual resources from the Greco-Roman-Christian traditions within which it remains rooted. ${ }^{19}$ My point is not to contrast this response with the Enlightenment's response to colonialism; doing so would lead to the familiar West versus Rest dichotomy and to charges of Eurocentrism, with emotive and ethical overtones that lead to an intellectual cul-de-sac. Rather, the purpose of recalling the social and intellectual context for the Enlightenment is to examine the ramifications of projecting assumptions about the meaning of Society that has evolved within one historical context to societies within which the meaning of Society remains to be defined and understood historically.

15. "Realism and social science" in Margaret Archer et al, eds, Critical Realism: Essential Readings (London: Routledge, 1998) 282.

16. Keywords: A Vocabulary of Culture and Society (London: Fontana Press, 1988).

17. Ibid at 293.

18. Ibid.

19. See Uberoi, supra note 6. 
A key proposition advanced here is that First and Third World societies are constituted through related but distinct processes: the first internal to the social context of capitalism's development, the second its external expansionist processes of imperialism and colonialism. These two processes, one centripetal and the other centrifugal, constitute two different types of societies with distinct features and properties that we recognize as First and Third Worlds. The basis for this differentiation remains under-theorized, however. Consequently, the Third World defined in antithetical terms to the First World as its "other" continues to haunt social theory. The ramifications of extending legal concepts and analytical categories developed through capitalism's centripetal or internal processes to societies constituted through its external or expansionist processes understood as colonialism and imperialism must inform TWSLS if we wish to address the fault line on which it is founded.

According to Karl Polanyi, for the first time in human history, capitalism dis-embeds from Society certain aspects of life associated with material provisions that it characterizes as economic aspects. ${ }^{20}$ It is not necessary to explore this argument for the purposes of this article except to reiterate Polanyi's point that the social transformation brought about by trade and commodification of land and labour was made possible by a philosophy that reduced collective social life-or companionship of the fourteenth century - to relations between individuals, on the one hand, and a relationship with nature through property relations on the other. ${ }^{21}$ Equally, what is dis-embedded from Society is re-embedded in institutions of states and markets created through the fiat of law. ${ }^{22}$ The scope and processes of embedding, dis-embedding, and re-embedding economic aspects of social life in capitalist and colonial societies produced two distinct types of societies with distinct attributes and properties. These processes have dramatically contrasting implications for the functionality or dysfunctionality of law and institutions in the two types of societies.

However, the obfuscation of the concept of Society in theory was a necessary condition for social transformations to occur in both types of societies. Methodologically, the obfuscation of Society as a theoretical category was achieved

20. The Great Transformation: The Political and Economic Origins of Our Time (Boston: Beacon Press, 1957).

21. For the difference between legal relationships with individuals and with nature under liberalism and within traditionally pluralist pre-colonial Indian society, see Radha D'Souza, Interstate Disputes over Krishna Waters: Law, Science and Imperialism (New Delhi: Orient Longman, 2006) at ch 3 [D'Souza, Krishna Waters].

22. Radha D'Souza, "The 'Rights' Conundrum: Poverty of Philosophy Amidst Poverty" in Reza Banakar, ed, Rights in Context: Law and Justice in Late Modern Society (Surrey: Ashgate, 2010) 55. 
in philosophical liberalism through three moves: (a) a privileging of epistemology over ontology; (b) philosophical dualism including the nature versus society and society versus ethics and aesthetics divisions in social theory; and (c) engagement with the problem of 'Universals' as the binary 'Other' of the 'Particular' in philosophy. It is to these moves that we need to turn our attention in social theory if we are to transcend the problem of binary categories and dualist methods entailed in the West versus Rest polarity that confounds TWSLS.

The institution of the state complicates the concept of Society. As Outhwaite points out, at first Society was seen as the third estate and a threat to the state; later it came to be squeezed within a territorial or institutional state. ${ }^{23}$ According to Outhwaite, when we speak of Society, we enter into a language game that licenses certain types of theoretical moves and not others, and that introduces an element of abstraction. ${ }^{24}$ Following Outhwaite, we cannot do without a concept of Society because the alternative is to have an ontology of the individual. ${ }^{25}$ As human actions presuppose social networks and social preconditions, some conception of the collective life becomes necessary. Liberalism straddles this question by squeezing society into the state, on the one hand, and reducing it to atomized individuals standing in contractual relations with the state on the other hand. This is the "civil society" of classical liberal theory. ${ }^{26}$ The concept of civil society is not to be conflated with Society, however. Civil society under capitalism refers to those institutions in the private sphere that underpin the economy. Society is much more.

The increase in the number of sociological and historical accounts of law in Third World societies does not do away with the need to answer the question, "What is Society?" Without answering this question, it is impossible to speak of the First and Third World without becoming mired in contradictions. In the absence of a theoretical understanding of Society, social theory is left with descriptions of societies. Descriptions alone do not provide the cues to make the causal connections between diverse events or facts, nor to identify trajectories of change. Sociological accounts describe social structures and the constraints that the structures impose on human life but tend to be deterministic because the descriptions of structural constraints are less able to integrate ethical and aesthetic

23. Supra note 15.

24. Ibid.

25. Ibid.

26. For the meaning of 'civil society' see Radha D'Souza, "Looking into the Crystal Ball: 'Civil Society' and 'Humanity' in the 21st Century" (2007) 18 Polylog: J Intercultural Philosophy 55 [D’Souza, "Crystal Ball"]. 
dimensions of social life. Descriptions of ethics and aesthetics emphasise agency and subjectivity but tend to be voluntaristic as they are less able to integrate structural constraints for social changes. For example, empirical accounts show real differences between the realities in First and Third World societies. These differences are echoed in everyday language. For example, newspapers and Western politicians routinely use expressions like 'Third World conditions' to describe deteriorating public services in the First World. Sociological accounts of First and Third World realities show the geo-historical mechanisms that structure the two worlds in very different ways even when they remain mutually constitutive and interdependent. Discourses in ethics and aesthetics reveal the desire for justice, freedom, and humanity, and emphasize the solidarity and unity of both worlds.

When the concept of Society is foregrounded in the understanding that Nature, Society, and Human Life are ontologically distinct but nevertheless related, it becomes possible to produce an epistemology that simultaneously accounts for differences between societies and sustains human impulses for solidarity and freedom. It becomes possible to argue that First and Third Worlds are specific conjunctures of Nature-Society-Human Life constituted through the geo-historical processes of capitalism and imperialism in different ways. Capitalism and imperialism reconstitute First and Third Worlds in definite ways and imbue the two societies with different characteristics and properties that are experienced as difference in everyday life. The freedoms and constraints of the two types of societies are experienced differently by people living in those societies. The source of solidarity, therefore, does not flow from eliminating difference discursively in ethics or analytically in social theory. Rather, it flows from the understanding that the desire for freedom is an ontological attribute of being human that must be respected universally. The ways in which human freedoms are curtailed are different for different types of societies. The differences are often cast in adversarial structural relations with other societies. This way of understanding unity and difference distinguishes between the desire for freedom in all people and the different modes of articulation of that desire in politics, which is prompted by the specificities of social formations in a given geo-historical moment. Bringing ontology to the centre stage of theory helps us to anchor the idea of Third World Society in theory, by whatever name it is called, without subsuming the differences between the societies, nor undermining the possibility of theory. It becomes possible to argue for solidarity without fetishizing the adversarial structural relations that the coupling of capitalism and imperialism creates between First and Third World societies or minimizing the imperatives of structural constraints. 
An understanding of Society at the ontological level invites us to epistemological inquiries that are ontologically aware, structurally astute, and empirically sensitive. Differences at the structural level do not negate human solidarities. Differences, while recognizing antagonistic interests of groups and societies, can take into account the different types of freedoms that each group or society seeks. They open up the possibilities of directionally different but ontologically consistent political programs for action. If A and B are standing in opposition but wish to reach midpoint - or another destination for that matter-they must travel in different, opposed directions to achieve the same objective. This possibility is foreclosed by liberal philosophy where sameness is contrasted with difference. The reduced emphasis on ontology in liberal philosophy precludes unity at the higher ontological level.

One category that produces endless conundrums in social theory is the Universals. In the Greco-Roman-Christian intellectual traditions, the Universal as a category in philosophy stands in opposition to the Particular. This way of framing the Universal as the opposite of the Particular in philosophy has produced binary concepts and dualistic methods wherein social theory must either abstract substance from form, as modernist theories do, or privilege the Particular over the abstractions, as postmodernism does. ${ }^{27}$ This is not the only way of understanding

27. Universalism and methods of abstraction in Western social theory and its critique by postmodern thinkers are deeply entrenched in social theory. Naturally there are a range of theoretical approaches to universalism and abstraction in modernist theories. Equally there is a range of critique of universalism from postmodernist perspectives and critiques of postmodern devaluation of theory from modernist perspectives. For modernist approaches to abstractions, see Andrew Sayer, Method in Social Science: A realist approach (London: Routledge, 1992) at ch 3; for differences in Marxist and Critical Realist methods, see JM Roberts, "Marxism and Critical Realism: The Same, Similar, or Just Plain Different?" (1999) 68 Capital \& Class 21; for a postmodern critique of meta-theories, see Jean-François Lyotard, The Postmodern Condition: A Report on Knowledge (Manchester: Manchester University Press, 1984); for Marxist critiques of postmodern approaches to meta-theories, see David Harvey, The Condition of Postmodernity: An Enquiry into the Origins of Cultural Change (Cambridge: Basil Blackwell, 1990). For a broader sociological account of modernism and postmodernism, see Zygmunt Bauman, Intimations of Postmodernity (London: Routledge, 1992); see also Zygmunt Bauman, Postmodernity and its Discontents (New York: New York University Press, 1997). For a critique of universalism in law from postmodern perspectives, see Peter Fitzpatrick, Modernism and the Grounds of Law (Cambridge: Cambridge University Press, 2001); for Third World perspectives on postmodernism, see Ziauddin Sardar, Postmodernism and the Other: The New Imperialism of Western Culture (London: Pluto Press, 1998). For general overviews of modernist and postmodernist approaches, see Lawrence Cahoone, ed, From Modernism to Postmodernism: An Anthology (Malden: Blackwell, 2003); Joe Doherty, Elspeth Graham \& Mo Malek, eds, Postmodernism and the Social Sciences (Basingstoke: Macmillan, 1992). 
Universals, however. In other philosophical traditions, Universals do not stand in opposition to Particulars as in the Greco-Roman-Christian traditions. Raja Ram Dravid, for example, argues that in the Indian traditions Universals are seen as distinct types of properties not necessarily opposed to Particulars. ${ }^{28} \mathrm{~A}$ move in social theory to reconceptualize categories like Universals and Particulars, drawing from philosophical traditions different from the Greco-Roman-JudeoChristian traditions, has the potential to provide a way out of the current impasse in theory produced by methodological dualism and binary concepts. It opens up possibilities of grounding concepts and theories in the materiality of the contemporary world and at the same time opens up pathways to reconceptualize freedom and emancipation for all.

Following these observations on the need to problematize Society in TWSLS, the question emerges, "What are the attributes and properties of societies constituted through the processes of colonialism and imperialism, and what is the role of law in the production of those attributes and properties that we recognize as the Third World?" The next three Parts follow this thread by examining three sets of binary frameworks used in TWSLS: first, comparative law versus TWAIL; second, economic versus cultural spheres in law; and third, legal centralism versus pluralism.

\section{WHAT IS 'ASIAN' ABOUT LAW IN ASIA?}

It may be useful to begin the discussion of comparative law versus TWAIL at the empirical level by considering widely accepted, everyday practices in the academic community on legal issues in the Third World context. In 2003, thirteen law schools in Asia formed the Asian Law Institute (ASLI) under the aegis of the National University of Singapore. ASLI held its inaugural conference in May 2004 in Singapore on the theme of "Law in Asia." Of the twenty-two panels on different sub-themes of law in Asia, only one panel, entitled "On Asian-ness: Traditions, Identity and Impact on Asia and Asians," was explicitly about Asian-ness. ${ }^{29}$ Papers presented on the panel addressed interpretations of

28. The Problem of Universals in Indian Philosophy (Delhi: Motilal Banarsidass, 1972).

29. The theme of the Asian Law Institute's May 2012 conference is "Asian Identity?" The question mark appears to suggest that the idea of 'Asian-ness' may be open to interrogation at the conference. In this connection, the theme is reminiscent of the debates in the 1990 s in social sciences on 'Asian values' that were driven largely by the success of the economies of some countries in the Asian region. See e.g. Fred Dallmayr, "Asian Values' and Global Human Rights" (2002) 52 Philosophy East and West 173; Michael C Davis, "Constitutionalism and Political Culture: The Debate Over Human Rights and Asian Values" 
Shar'ia in the region, Buddhist and Christian perspectives on law, and law in the Tang dynasty in China. All other panels were about applying international law, public and private, and principles of modern law to various fields in the economy - and, related to it, human rights, labour, and environment standards in Asian states. Law in Asia was about extending the developments in international law and dominant capitalist states to Asia and, at best, being vigilant about how the extensions might affect the state and economy in the region. So one might ask what is 'Asian' about Law in Asia?

ASLI went on to publish a journal entitled Asian Journal of Comparative Law. There are several other Asian law journals. ${ }^{30}$ Like the panels at the ASLI conferences, a sweeping overview of the subjects addressed in the Asian law journals reflect a similar pattern, where modern law addresses problems in economics and related fields like labour, environment, and human rights; traditional law-often religious law-addresses cultural issues concerning family and inheritance; and land tenure falls somewhere in between. This architecture of law in Asia-where the jurisdiction of modern law prevails over economic spheres and the jurisdiction of traditional law prevails over cultural spheres outside the economy-is common to most Third World countries. It also mirrors the wider society it services where, generally speaking, the cultural sphere is governed by traditional law and the economic sphere is governed by modern law.

Comparative law provides the analytical framework for dominant approaches to law in Asia as evidenced at the conference, or for that matter, dominant TWSLS. Comparative law is methodologically weak. As Burkhard Schafer points out, comparative law starts with an assumption of comparability and some form of functionalism, in that it assumes some correlation between legal forms and social functions and draws on legal history to establish the correlation. ${ }^{31}$ Comparative law and legal historiography in dominant scholarship, thus, share common presuppositions-both are premised on the rationality of legal responses to societal demands. ${ }^{32}$ For legal systems to be compatible, writes Schafer, it is

(1998) 11 Harv Hum Rts J 109; Amartya Sen, "Human Rights and Asian Values" (Sixteenth Morgenthau Memorial Lecture on Ethics and Foreign Policy, delivered at the Carnegie Council on Ethics and International Affairs, 25 May 1997); Mark R Thompson, "Whatever Happened To 'Asian Values'? " (2001) 12 J of Democracy 154.

30. See e.g. Asian Journal of International Law; Asian Law Journal; The Australian Journal of Asian Law; East Asia Law Review; Asian American Law Journal; Columbia Journal of Asian Law; and Asian Journal of International Law.

31. "Form Follows Function Fails - as a Sociological Foundation of Comparative Law" (1999) 13 Social Epistemology 113.

32. Ibid at 126 . 
sufficient they have a shared core: "That is, we either have to identify a historical core programme (legal history), or extrapolate one logically (comparative law)." 33

Schafer draws from comparative legal scholarship on common law and continental civil law to explain how the core of Roman law provides the basis for explanations of the divergent "development of legal systems that share historical roots. ${ }^{34}$ These attempts to strengthen the epistemological foundations of comparative law work where shared historical, cultural, and philosophical traditions provide a repertoire of conceptual resources for the development and communication of ideas between the societies within which the legal systems operate. This is seen in common law and continental civil law systems underpinned by a core that is derived from Roman law. The absence of an intersubjective order makes a shared core for comparative law for legal systems in Third World and First World societies methodologically problematic. Is comparative law possible where the legal histories do not provide a shared core? ${ }^{35}$ More importantly, in the case of Asia and other Third World societies where comparative law dominates the economic sphere, the pressing question is this: "Is it possible at all to cast economic and social spheres into legal systems with radically different normative, ethical, institutional, and conceptual 'grundnorms'"?36

We shall return to this architecture of law again in the next section. Suffice it to note here that such a problem does not exist in the Euro-American capitalist societies. ${ }^{37}$ While Euro-American law in every sphere has transformed and evolved over time, it remains grounded in, and inspired by, various strands of Greco-Roman-Christian intellectual, cultural, and legal traditions. Dissent, change, and evolution all refer back to, and continue to draw on, the conceptual and philosophical resources from those traditions. Indeed, modern law is a product of those traditions. ${ }^{38}$ In Third World societies, the gap between culture and economy

33. Ibid.

34. Ibid.

35. This raises a related question for 'Asian-ness': Is comparative law an adequate framework for Asian countries that arguably share intersubjective social features and shared experiences of colonialism?

36. Used here in Kelsen's sense of positing a basic set of grounds from which all other legal norms may be derived. Hans Kelsen, Pure Theory of Law (Berkeley: University of California Press, 1967) at 8-9.

37. First Nations in North American settler capitalist societies historically and structurally share common features with Third World societies, even if they exist within capitalist states. For distinctions between colonial and capitalist states see Radha D'Souza, "The 'Third World' and Socio-Legal Studies: Neo-Liberalism and Lessons from India’s Legal Innovations" (2005) 14 Soc \& Leg Stud 487 [D’Souza, “Socio-Legal Studies”].

38. See Geoffrey Samuel, "Roman Law and Modern Capitalism" (1984) 4 LS 185; Michael E Tigar \& Madeleine R Levy, Law and the Rise of Capitalism (New York: Monthly Review 
manifests in law as two distinct domains of law. This gap in law-between the historical past where the roots of culture lie and the geographical present where global economic relations play out between states, on the one hand, and its manifestation as a rupture in the intellectual moorings of its economy and culture, on the other hand-is under-theorized in TWSLS. What John Comaroff ${ }^{39}$ asks about studies on colonialism and law may be asked about TWSLS more generally. Summarizing the trajectory that seems to have brought studies of law and colonialism to a resting point, Comaroff argues that there is a convergence and consensus on colonial law as being both an instrument of domination and a site of resistance. He asks, "Is there anything more to say on the topic, other than to offer further historical and/or ethnographic illustration?"40 Although Comaroff answers the question in the affirmative, what is proposed by way of a future agenda for law and colonialism studies is to develop a more nuanced understanding of complexities of the role of law in colonization by undertaking empirically grounded and methodologically improved accounts of law in colonialism. Such approaches could certainly produce better socio-legal studies of the Third World. Whether it will shift the grounds of philosophy of law or social theory is a pressing question. In any event, philosophical questions about law in society cannot be deduced from sociological accounts of law. Nor is it possible to arrive at a theory of Society from sociological accounts. Sociological accounts presuppose concepts and analytical frameworks grounded in social philosophy.

In contrast to comparative law approaches in dominant Asian and other regional legal studies, TWAIL claims to be a movement within international law that seeks to study international law from Third World perspectives. Although TWAIL scholars defend the use of the term Third World, there is considerable ambiguity in what is meant by the term and the conceptual basis for its use. For Obiora Okafor, Third World is a contingent but useful category that is selfreferential. ${ }^{41}$ Third World therefore becomes a question of identity. For Makau Mutua the term Third World is "a stream of similar historical experiences across virtually all non-European societies that has given rise to a particular voice, a form of intellectual and political consciousness [and] captures the oppositional dialectic between the European and the non-European." 42 The TWAIL conference

Press, 1977); Franz Wieacker, “The Importance of Roman Law for Western Civilization and Western Legal Thought” (1981) 4 BC Int'l \& Comp L Rev 257.

39. “Colonialism, Culture, and the Law: A Foreword" (2001) 26 Law \& Soc Inquiry 305.

40. Ibid at 307.

41. Supra note 7.

42. "What is TWAIL?" in Paul B Stephan III, Proceedings of the Ninety-fourth Annual Meeting of the American Society of International Law, Washington DC, 2000 (Washington: American 
held at Albany Law School in April 2007 defined Third World as "a contingent and shifting space of engagement and interaction of differences that are irreconcilable sometimes, and overlapping and reinforcing in others." 43

The object of knowledge for TWAIL scholars is international law, not the Third World. TWAIL scholars aim to provide a perspective on international law from the vantage point of marginalized nations. TWAIL approaches deconstruct and contextualize the ways in which international law is formed through the encounter of European powers with colonized societies. ${ }^{44}$ Reversing the perspective from European to non-European does not, however, change the conceptual frames that inform international law, nor does it reveal what is entailed in projecting those concepts onto Third World realities. TWAIL approaches embed the Other in epistemology, even when challenging it empirically, and remain constrained by the West versus Rest dichotomy.

In their normative standards, TWAIL scholars remain modernist inasmuch as they seek ethical interventions to reform international law so that it lives up to its normative claims of equality and non-discrimination. It is beside the point whether such approaches are offshoots of Northern scholarship or not..$^{45}$ What is important is whether the scholarship falls back on moral or ethical transformation and voluntarism to ground ideas of freedom and equality between all societies and whether or not it opens pathways for transformation where freedom and equality between societies qua societies are grounded in the materiality of a world based on relations of super- and subordination.

Andrew Sunter argues that TWAIL approaches may be described as naturalized epistemological inquiries. ${ }^{46}$ As such, they rely on a posterior empirical knowledge to arrive at a priori claims. TWAIL approaches, therefore, fall back on philosophical empiricism in the form of past experiences of the Third World to critique international law. These approaches reify the status quo by grounding the possibility of transcendence in past experiences. While this critique and deconstruction make an important contribution to our understanding of the role of international law in sustaining inequalities between societies in the past and present, deconstruction

Society of International Law, 2000) 31 [Mutua, "What is TWAIL?"].

43. Sec Albany Law School, "The Third World and International Law Conference TWAIL III" (20 April 2007), online: Australian National University <http://cigj.anu.edu.au/cigj/link_ documents/Events/assoc_events/TWAILBrochure.pdfs.

44. See Antony Anghie, Imperialism, Sovereignty, and the Making of International Law (Cambridge, UK: Cambridge University Press, 2005).

45. C.f. Antony Anghie \& BS Chimni, "Third World Approaches to International Law and Individual Responsibility in Internal Conflicts” (2003) 2 Chinese J Int'l L 77.

46. “TWAIL as Naturalized Epistemological Inquiry" (2007) 20 Can JL \& Jur 475. 
alone does not suffice for transcendence of the West versus Rest polarity. Nor does it help to redefine the meaning of freedom. We remain in what Teemu Ruskola calls the "hermeneutical loop." 47 We do not have a way of answering the question, What is 'Asian' about Asian law? Fear of essentialism and reductionism, on the one hand, and universalism and meta-theories without social content, on the other hand, prevents escape from hermeneutical loops.

Some scholars have argued that there is a spatial tension in the theorypractice dialectic of knowledge production in that theory production remains located in the First World but is based on experiences produced in the Third World. ${ }^{48}$ While locations and spatial dialectics of knowledge production are important, we must be careful not to over-determine the case for location to the detriment of intellectual creativity and human solidarities. Rather, the problems may lie in philosophical dualism, which dominates Modernist and Enlightenment thinking. Philosophical dualism produces conceptual deadlocks by locking binary categories into oppositional positions and thereby forestalling transcendence and emergence. As Roy Bhaskar shows in his work Dialectics: Pulse of Freedom, thesis and antithesis share common grounds. ${ }^{49}$ The hermeneutical cycles create and recreate familiar patterns in the analytical frameworks that inform knowledge of the Third World and continue to reproduce unequal relations even after several centuries of resistances and solidarities to end them. The result is pessimism and obeisance to what is described metaphorically as the "empire of law."50

In the light of these observations about TWSLS, how may we understand the dichotomy, exemplified by the ASLI conference, between modern or economic domains, on one hand, and traditional or cultural domains, on the other? The next Part explores this question by interrogating the public/ private divide in law.

\section{TRADITIONAL IN CULTURE AND MODERN IN ECONOMY?}

The opposing directionality of capitalism and imperialism in the constitution of societies in the First and Third Worlds produces asymmetries in the substance and form of concepts used to analyze modern societies. In other words, the

47. “Legal Orientalism" (2002) 101 Mich L Rev 179 at 232.

48. See e.g. Saraswati Raju, 'Production of Knowledge: Looking for 'Theory' in 'Familiar' Places?" (2006) 37 Geoforum 155.

49. (London: Verso, 1993).

50. C.f. Mark Goodale, "Empires of Law: Discipline and Resistance within the Transnational System" (2005) 14 Soc \& Leg Stud 553. 
geo-historical content of concepts in social theory is not comparable even when comparable vocabulary is used. This is more significant in law because legal concepts define social relations and reify their normativity. Law-in particular the foundations of positive law-rests on definitions. In order to understand the economic-modern versus cultural-traditional architecture of law in the Third World, it becomes necessary to problematize the language of law by interrogating core legal categories in light of insights provided by historical and sociological critique. It is necessary to go beyond comparing and contrasting the observable effects of law in different nation-states, as in sociological and anthropological studies, and to begin building a philosophical foundation for TWSLS.

How the asymmetries in the substance and form of legal concepts sustain the divide between modern law in the domain of the economy and traditional law in the domain of culture in the legal architecture of Third World societies may be exemplified by interrogating the use of the legal categories of "public" and "private" in law. The public/private divide is a structural feature of modern law. Legal theory works on the premise that law has two branches that operate in two different social spheres. Jowitt's Dictionary of English Law defines Public Law it as follows:

[L]aw is either public or private. ... Public law is that part of the law which deals with the State, either by itself or in its relations with individuals, and is called constitutional, when it regulates the relations between the various divisions of the sovereign power; and administrative, when it regulates the business which the state has to do... . ${ }^{51}$

To the contrary:

Private or civil law deals with those relations between individuals with which the state is not directly concerned: as in the relations between husband and wife, parent and child, and the various kinds of property, contracts, torts, trusts, legacies, the right recognized by the rules of admiralty, etc. ${ }^{52}$

The two branches of law limit the role of the state and sovereign power in First World societies. The public/private divide is not as neat in reality as it is conceptually, nor is it uncontested. Over time, the boundaries have been contested, altered, and realigned. ${ }^{53}$ More recently, globalization has revived debates on the public/private

51. The Late Right Honourable The Earl Jowitt \& Clifford Walsh, Jowitt's Dictionary of English Law, 2d ed (London: Sweet \& Maxwell, 1977) sub verbo "Law" at 1069.

52. Ibid.

53. For debates and discussions on the public/private divide, see $130 \mathrm{U}$ Pa L Rev (1982). See also Dawn Oliver, Common Values and the Public/private Divide (London, UK: Butterworths, 1999); Michael Taggart, "The Nature and Functions of the State" in Peter Cane \& Mark Tushnet, eds, The Oxford Handbook of Legal Studies (New York: Oxford University Press, 2003) 101; Margaret Thornton, ed, Public and Private: Feminist Legal Debates (Melbourne: 
divide just as the debate revived after the end of World War II in the context of rebuilding economies and society and the "welfare states" in capitalist societies. ${ }^{54}$ Nevertheless, the two spheres of law continue to define the role of the state in society and to provide a point of reference for the architecture of law. What is important for our purposes is that in the history of the First World, normatively and conceptually, economy and culture simultaneously formed part of the private spheres of law and defined the boundaries of the state. Land, trade, and property rightsalongside marriage, inheritance, adoption, and such — were part of the private spheres where the state's role needed to be policed against incursions. When statutes trespassed into the private spheres, they required special justifications. Classical liberal theory devoted considerable energy to keeping the state at arm's length from the economy and from culture. Equally important is that in policing the boundaries, the public/private divide continued to rely on the extended history of the concept in Roman law. ${ }^{55}$ Indeed the public/private concepts and divisions developed through contested histories in Europe and contributed to the development of capitalism and imperialism during all its phases. ${ }^{56}$ It is not surprising that the public/private divide became the focus of debate in the globalization phase of capitalism and imperialism. ${ }^{57}$

In contrast, colonial law extended the conceptual categories of public/private spheres to colonial societies, but infused them with different socio-economic content. Colonial rule gathered a diverse range of castes, communities, tribes, and nationalities under the umbrella of the colonial state. Economic matters such as contracts, easements, trade, forests, fisheries, minerals, and land-traditionally within the private sphere in Europe under Roman law traditions - were brought under state regulation through public law statutes. Even contracts, the sacred cow

Oxford University Press, 1995).

54. For debates on the public/private divide in the wake of globalization, see Carl Emery, "Public Law or Private Law?: The Limits of Procedural Reform" [1995] PL 450; Sandra Fredman \& Gillian S Morris, "The Costs of Exclusivity: Public and Private Re-examined" [1994] PL 69; Mark Freedland, "Government by Contract and Public Law" [1994] PL 86; Geoff Pearson \& Michael Salter, "Getting Public Law Back into a Critical Condition: The Rule of Law as a Source for Immanent Critique" (1999) 8 Soc \& Leg Stud 483.

55. For the role of Roman law in Western civilization, see Franz Wieacker, "The Importance of Roman Law for Western Civilization and Western Legal Thought" (1981) 4 BC Int'l \& Comp L Rev 257; for the place of Roman law in modern capitalism, see Geoffrey Samuel, "Roman Law and Modern Capitalism" (1984) 4 LS 185; for the role of European law in the development of capitalism, see Michael E Tigar \& Madeleine R Levy, Law and the Rise of Capitalism (New York: Monthly Review Press, 1977).

56. Ibid.

57. Anghie \& Chimni, supra note 45. 
of private law, were legislated into existence through public law in the colonies. ${ }^{58}$ Colonial law introduced a field of law called "personal law" or "tribal law." Matters concerning family, inheritance, succession, marriage, divorce, and adoption were left to be governed by the religious and tribal norms of diverse communities. Personal/tribal law shrunk the private sphere in the colonies and expanded the public sphere by subsuming the economy within the public sphere. ${ }^{59}$ Although the concepts of public and private law are routinely used as foundational legal categories everywhere, they denote different socio-economic and geo-historical realities and social spheres in the Third World. In the First World, the public/private divide limited the role of the state and defined sovereign powers. In the Third World, it expanded the role of the state and shrank the private sphere. Retaining the legal language of the public/private divide fetishized the assumption of sovereignty over resources and populations that were traditionally in the private sphere in the European legal tradition. More significantly, it enabled the colonial state to incorporate diverse communities into the political economy of colonialism under the umbrella of the modern colonial state. The modern state structure in the Third World has continuities with the colonial state. The economic-modern versus cultural-traditional law divide, in retrospect, was foundational for indirect rule, which subsequently became the dominant mode of imperial governance globally. Arguably, it was that architecture of law that made formal decolonization possible under the United Nations System at the end of World War II.

The theoretical assumptions underlying personal and tribal law are important. The assumption is that culture can somehow continue to be practiced without its moorings in the materiality of the economy. Conversely, there is the assumption that somehow the economy will transform and modernize social relations. Both these assumptions are mired in contradictions. Inasmuch as all cultures must be grounded in the materiality of societies, the assumption that cultural practices can be continued even after the political economy has changed is fundamentally flawed. Sir Henry Maine argued that colonial societies would progress from status-based to contract-based relations in the same way as had happened under European capitalism. ${ }^{60}$ This social Darwinism in legal theory was at odds with the colonial

58. Sec e.g. Stuart Banner, "Conquest by Contract: Wealth Transfer and Land Market Structure in Colonial New Zealand" (2000) 34 Law \& Soc'y Rev 47; DA Washbrook, "Law, State and Agrarian Society in Colonial India" (1981) 15 Mod Asian Stud 649.

59. For the politics of tribal and state law in colonial South Africa, see Mahmood Mamdani, Citizen and Subject: Contemporary Africa and the Legacy of Late Colonialism (Princeton: Princeton University Press, 1996).

60. Ancient Law: Its Connections with the Early History of Society and Its Relation to Modern Ideds (New York: Henry Holt and Company, 1881). 
imperative of imperial governance that necessitated incorporation of local family and tribal structures within the wider colonial state. ${ }^{61}$ Consequently, contractual relations in the economy did not evolve into general contract forms of social relations in all spheres of social life. ${ }^{62}$ The processes that extended public/private concepts in law to different socio-historical realities of the Third World created a structural schism within Third World societies, where two sets of values, norms, institutions, and laws - one for the economy, another for culture-regulate two aspects of society as if the two were unrelated.

The structural schism between economy and culture is a characteristic of Third World societies, an attribute acquired through the socio-economic and geo-historical experiences of colonialism. This attribute assumes diverse manifestations depending on local histories, politics, and other specificities. The schism has a profound influence on institutions in Third World societies. Economic institutions continue to be driven by impulses for harmonization from dominant capitalist economies, and social institutions continue to be driven by the impulses of nationalism and culture. The schism in the legal architecture of the Third World sustains the swings between what Clifford Geertz calls "epochalism" (impelled by economic modernization) and "essentialism" (impelled by cultural nationalism) that is so typical of Third World nationalism. ${ }^{63}$ The schism produces traumatic internal upheavals. Can Iran remain a player in the world oil markets, emerge as a nuclear power, and at the same time adhere to pristine Islamic traditions under the same constitution? How does one fulfill the obligation to care for one's unemployed family members in an extended family when the labour market is based on the sale of individual labour power? If Hindu

61. See e.g. ibid.

62. The absence of contract as the general form of social relations in all spheres of social life in the Third World, as it is in the First World, enables the World Bank to insist on law reforms that commit to contracts and private property as a condition for continued financial assistance. See e.g. Lawrence Tshuma, "The Political Economy of the World Bank's Legal Framework for Economic Development" (1999) 8 Soc \& Leg Stud 75; Fidler, supra note 3. As Third World economists have pointed out, the full development of contractual relations was impossible in the conditions of 'underdevelopment' that characterized the Third World. Sec e.g. Hamza Alavi, Capitalism and Colonial Production (Kent: Croom Helm, 1982); Hamza Alavi, "India and the Colonial Mode of Production" (1975) 10:33-35 Economic and Political Weekly 1235; Amiya Kumar Bagchi, "Colonialism in Classical Political Economy: Analysis, Epistemological Broadening and Mystification" (1996) 12 Stud Hist 105; Amiya Kumar Bagchi, "Foreign Capital and Economic Development in India: A Schematic View" in Kathleen Gough \& Hari P Sharma, eds, Imperialism and Revolution in South Asia (New York: Monthly Review Press, 1973) 43.

63. The Interpretation of Cultures: Selected Essays (London, UK: Fontana Press, 1993). 
widows must work because the labour market does not recognize family labour, can the moral authority of Hindu traditions alone stop her from remarrying? And how do tribes maintain tribal authorities and traditional structures of governance when the economy has slipped away from the tribal society?

The individual as an atomized, irreducible legal category, standing in contractual relations with the state, created the conditions for citizenship in the First World in the wake of capitalism. In the Third World, by contrast, ethnic, religious, and linguistic communities were co-opted into markets and assigned places within market institutions. Amy Chua shows how, in the Third World, the nationalization and privatization programs prompted by the international economy impact specific communities in definite ways, depending on their positions in the economy. ${ }^{64}$ In the Third World, the impacts of international economic policies emanating from the centres of capital are experienced as ethnic and racial tensions differently by different communities. ${ }^{65}$ For example, in the context of Malaysian colonial history, because of the respective locations of Tamils, Malays, and Chinese in the economy and market institutions as communities, a policy that adversely affects the rubber industry will affect Tamils, agricultural policies will affect Malays, and trade policies will affect the Chinese. Widespread, divisive ethnic conflicts in the Third World may have to do with a legal architecture where cultural aspirations are cut adrift from political economy and where citizenship itself remains collective rather than individual.

We are witness to the political economy of globalization, which is followed by cultural conflicts. ${ }^{66}$ Contrary to the expectations of global solidarity movements that campaigned for the rights of people in the wake of globalization, in Thailand, people embraced religion and karma in preference to rights against the state; and contrary to expectations, neoliberalism had the effect of expanding the scope of shar'ia in Aceh, a region with long traditions of legal pluralism going back to pre-colonial times. ${ }^{67}$ This 'choice,' if it may be called that, ought not to surprise

64. Amy L Chua, "The Privatization-Nationalization Cycle: The Link between Markets and Ethnicity in Developing Countries" (1995) 95 Colum L Rev 223.

65. For an analysis in the context of Rwanda, see Mahmood Mamdani, When Victims Become Killers: Colonialism, Nativism, and the Genocide in Rwanda (Princeton: Princeton University Press, 2001).

66. For the linkages, see Amy Chua, World on Fire: How Exporting Free Market Democracy Breeds Ethnic Hatred and Global Instability (New York: Doubleday, 2003).

67. See David M Engel, "Globalization and the Decline of Legal Consciousness: Torts, Ghosts, and Karma in Thailand" (2005) 30 Law \& Soc Inquiry 469; Arskal Salim, "Dynamic Legal Pluralism in Indonesia: The Shift in Plural Legal Orders of Contemporary Aceh" (Max Planck Institute For Social Anthropology, Working Paper No 110, 2009), online: <http:// www.eth.mpg.de/cms/en/publications/working_papers/>. 
us if we bear in mind the constitution of public and private spheres. Constituted with reference to economic interests rather than citizenships, it is unsurprising that everywhere in the Third World, economic development after independence remained state-centred. It is hardly surprising that international organizations like the World Bank, the International Monetary Fund, and the World Trade Organization were able to restructure Third World states everywhere through contractual agreements with states on lending policies in Structural Adjustment Programs. ${ }^{68}$

The unproblematic use of the language of rights by protest movements - as if it refers to the same type of citizen-state relationship as in the First World-has the effect of reifying and embedding unequal relations between societies, even when the intention is to the contrary. ${ }^{69}$ Using the same vocabulary to analyze different social realities has the effect of reifying unequal relations between First and Third Worlds. The language of public/private in law obscures the social realities in the Third World. The use of a common vocabulary suggests comparable meanings and substance. ${ }^{70}$ The field of comparative law helps to point out similarities and dissimilarities at the descriptive and definitional levels, but it does not do the same with respect to the geo-historical causal processes that produce radically different effects of law in different societies. Critical theories reverse the vantage point from similarities to dissimilarities but remain methodologically within dualist frameworks working with binary categories. ${ }^{71}$ The structural schism also means that the tensions in Society, because of the structural disjuncture between economy and culture, remain unresolved. This irresolution is another attribute of Third World societies, in which law, imperial agendas and global solidarities, contribute in turn to reproducing the schism in these societies.

The co-existence of multiple legal systems in the cultural sphere and in the informal economy is commonly analyzed through the framework of legal pluralism. Legal pluralism, as an analytical framework, draws on law in Third World societies to a large extent because of the apparent co-existence of different

68. For an account of international organizations as lawmakers, see José E Alvarez, International Organizations as Law-makers (Oxford: Oxford University Press, 2005).

69. See Radha D'Souza, “Law and 'Development' Discourses About Water: Understanding Agency in Regime Changes" in P Cullet et al, eds, Water Governance in Motion: Towards Socially and Environmentally Sustainable Water Laws (Delhi: Cambridge University Press, 2010) 477 [D'Souza, Water Governance]; Radha D’Souza, "Liberal Theory, Human Rights and Water-Justice: Back to Square One?” (2008) 11 Law Soc Just \& Glob Dev J.

70. For similar arguments on the distinctions between 'civil society' and 'humanity' in social theory, see D'Souza, "Crystal Ball," supra note 26.

71. Ibid. See also Part II, above, on TWAIL. 
normative orders that characterize Third World societies more than others. Given the influence and popularity of legal pluralism as an analytical framework for law in Third World societies, it is this concept that we must turn to next in order to expand upon the economic-modern versus cultural-traditional architecture of law in Third World societies.

\section{LEGAL PLURALISM, CENTRALISM, AND THIRD WORLD SOCIETIES}

Beginning with attempts to theorize the meaning of law in the writings of Eugen Ehrlich, Bronislaw Malinowski and others, ${ }^{72}$ more recent expositions see legal pluralism variously as co-presence of diverse legal systems in society; ${ }^{73}$ as processual; ${ }^{74}$ as postmodern, inspired by polycentricity; ${ }^{75}$ as autopoiesis; ${ }^{76}$ as praxiological; ${ }^{77}$ and as anti-hegemonic. ${ }^{78}$ This brief snapshot does not attempt to capture the nuances and orientations of the diversity in the approaches to legal pluralism. ${ }^{79}$ The purpose of the snapshot is to make the point that the idea of legal pluralism is an enduring one with an extended genealogy in socio-legal studies; that it uses analytical, empirical, and pragmatic methods; that it is popular in anthropological and sociological studies of law; and that the debates on legal

72. Roscoe Pound, "An Appreciation of Eugen Ehrlich" 36 Harv L Rev 129 at 130, 145; Marc Hertogh, ed, Living Law: Reconsidering Eugen Ehrlich (Oxford: Hart Publishing, 2009); Bronislaw Malinowski, $A$ Scientific Theory of Culture, and other essays (Chapel Hill: The University of North Carolina Press, 1944); For more recent writings on legal pluralism see Baudouin Dupret, Maurits Berger \& Laila al-Zwaini, Legal Pluralism in the Arab World (The Hague, Netherlands: Kluwer Law International, 1999); Helene Maria Kyed, “The Politics of Legal Pluralism: State Policies on Legal Pluralism and Their Local Dynamics in Mozambique" 59 J Legal Pluralism 87; Arskal Salim, supra note 67 at 1-18; Jeremy Weber, "Legal Pluralism and Human Agency" 44 Osgoode Hall LJ 167.

73. See e.g. John Griffiths, “What Is Legal Pluralism?” (1986) 24 J Legal Pluralism 1 [Griffiths, "Legal Pluralism"].

74. See e.g. Sally Falk Moore, Law as Process: An Anthropological Approach (Oxford: James Currey, 2000).

75. See e.g. Boaventura de Sousa Santos, Toward a New Legal Common Sense: Law, Globalisation and Emancipation (London, UK: Butterworths LexisNexis, 2002).

76. See e.g. Gunther Teubner, Law as an Autopoietic System, translated by Anne Bankowska \& Ruth Adler (Oxford: Blackwell, 1993); see also Niklas Luhman, Law as a Social System, translated by Klaus A Ziegert (Oxford: Oxford University Press, 2004).

77. See e.g. Baudouin Dupret, Maurits Berger \& Laila al-Zwain, eds, Legal Pluralism in the Arab World (The Hague: Kluwer Law International, 1999).

78. Mutua, "What is TWAIL?" supra note 42.

79. For a summary of the different orientations to legal pluralism, see Jeremy Webber, "Legal Pluralism and Human Agency" (2006) 44 Osgoode Hall LJ 167. 
pluralism have changed over time. While the analytical and conceptual engagement with legal pluralism do not limit legal pluralism to Third World or colonial societies, the empirical studies on legal pluralism are dominated by examples of multiple legal systems under colonialism and in contemporary Third World societies. The point here is not about legal pluralism as such, but rather about the epistemological implications of the use of legal pluralism for analysis of Third World societies.

At the core of legal pluralism is the idea that law cannot be limited to state-centred law and that multiple systems of law operate in society. It is a reaction to the privileging of state law in modern societies. The idea of legal pluralism developed in juxtaposition to state law. Later strands in legal pluralist thought engage the meaning of law and the state-society context within which law, however understood, operates. The idea that state-centred law is the only legitimate law is an idea that emerged with capitalism. John Griffiths refers to this as the ideology of legal centralism. According to Griffiths:

An important part of the ideological heritage of the bourgeois revolutions and liberal hegemony of the last few centuries is the complex of ideas concerning the nature of law and its place in social life. According to what I shall call the ideology of legal centralism, law is and should be the law of the state, uniform for all persons, exclusive of all other law, and administered by a single set of state institutions. To the extent that other, lesser normative orderings, such as the church, the family, the voluntary association and the economic organization exist, they ought to be and in fact are hierarchically subordinate to the law and the institution of the state. ${ }^{80}$

From this, Griffiths goes on to develop the argument that legal pluralism is concomitant to social pluralism. In other words, as social action always takes place in multiple semi-autonomous fields, there are multiple fields of law reflective of the wider social fields. ${ }^{81}$ It is worth dwelling on Griffiths' idea that the primacy given to state law is a heritage of bourgeois revolutions. From the geo-historical experiences of Western societies, is it possible to abstract the proposition that legal centralism is ideology everywhere and legal pluralism the reality, as Griffiths does?

In the geo-historical context of capitalism, legal pluralism in the First World refers to those unrecognized, invisible, law-like relations, facilitative of the smooth functioning of society. Legal pluralists in the First World argue that these contributions of non-state law must be valued and recognized. Equally, since the bourgeois revolutions that established capitalism as the social order in the West,

80. Griffiths, "Legal Pluralism," supra note 73 at 2.

81. Ibid. 
more and more aspects of social life have been commodified. Stated differently, more and more aspects of social life are brought under legal centralism by making them contingent on incorporated entities created by the fiat of law. Even everyday social support activities like caring for the sick and elderly, protection from crime, and caring for children rely on provisioning services through legally sanctioned entities like cancer victims support groups, neighbourhood watch groups, or childcare centres, whether voluntary or paid.

In contrast, in the Third World, it is legal pluralism that is ideological. Legal pluralism in the Third World holds out the possibility of the co-existence of imperialism and nationalism, a modern economy driven by the centres of capital like the G8 nations, where nationalism comes to be defined in terms of racial identities and cultural practices. It fetishizes the ways in which institutional developments in the Third World reproduce relations of super- and subordination in the economy on the one hand, and anchors the right to self-determination in essentialized identities on the other.

It is important to bear in mind that both markets and states are complexes of laws. As creatures of the law, they provide the institutional infrastructure for capitalism. ${ }^{82}$ In the Third World, modern institutions (as complexes of laws) developed largely with regard to those aspects of society that were operationally brought under the capitalist economy through imperialism. ${ }^{83}$ Therefore, large swathes of economy and society continue to remain outside modern institutions. For example, the so-called informal sectors of the economy in the Third World that dominate the literature on poverty and development exist outside state centralism. ${ }^{84}$ When viewed through an empirical lens, the informal economy appears as diversity and validates legal pluralism. However, as an analytical framework for law in the Third World, legal pluralism sustains the wider political economy of capitalism and imperialism in reproducing two types of labour markets - formal and informalwhere the formal labour market is tied to global political economy and the informal to subsistence and survival. In the wider context of asymmetrical power relationships, legal pluralism plays an ideological role in imperial governance in a number of ways.

First, legal pluralism rationalizes the politics of exclusion. The positive connotations and values attributed to legal pluralism means that the exclusion

82. See D'Souza, Water Governance, supra note 69.

83. For how this occurred in the context of Indian constitutional history, see D'Souza, "SocioLegal Studies," supra note 37.

84. The recognition of a large informal economy prompted the influential work of Hernando de Soto. See Hernando de Soto, The Mystery of Capital: Why Capitalism Triumphs in the West and Fails Everywhere Else (New York: Basic Books, 2000). 
of some segments of society from modern institutions is rationalized. It obscures the reality that co-existence is not a voluntary or desirable state of affairs. For example, workers in the informal sector may improvise law-like norms and codes for survival. These norms and codes exist alongside those in the formal sector, where workers are protected by modern law. The co-existence of the two sectors is rationalized as plural orders. The creativity of the informal sector workers is celebrated. ${ }^{85}$ This celebration obscures the ways in which imperialism constitutes two classes of workers - one protected by trade unions and rights of collective bargaining and another who are excluded from legal protection and left to their own creative strategies for survival. ${ }^{86}$ The normative idea, however, remains one where trade unions and rights of collective bargaining are recognized by the state and extended to all, even when large sections of the workforce must necessarily be excluded from the normative ideal because of the structure of global labour markets. While legal pluralism invites us to recognize the normative and regulatory aspects of informal sectors of the economy and to celebrate the human spirit that challenges its exclusion, it fetishizes the exclusion of large sections of the workforce from the norms and regulations of the state and conceals the reality that not all workers in the Third World can be protected by law. This example

85. Legal pluralism produces curious outcomes. For example, the well-known Marxist geographer David Harvey analyzes the shift in the international divisions of labour from Fordist to post-Fordist modes of production and concludes that "the turn to more flexible labor processes could be seen as an opening to a new era of democratic and highly decentralized labor relations and co-operative endeavours." See David Harvey, The Condition of Postmodernity: An Enquiry into the Origins of Cultural Change (Oxford: Basil Blackwell, 1990 ) at 353. Hernando de Soto, a well-known neo-liberal advocate of privatisation and private property rights, also recognises de facto legal pluralism but argues for including such plurality as part of a regime of private property rights. He writes, "Outside the west, extralegal social contracts prevail for a good reason: They have managed much better than formal law to build on the actual consensus between people about how their assets ought to be governed. Any attempt to create a unified property system that does not take into account the collective contracts that underpin existing property arrangements will crash into the very roots of the rights most people rely on for holding onto their assets." See Hernando de Soto, The Mystery of Capital: Why Capitalism Triumphs in the West and Fails Everywhere Else (London: Bantam, 2000) at 171. Others have recognised that the need for survival of the poor in the Third World produces legal pluralism but argue that it has the potential to be used in counter-hegemonic ways. On globalization and labour policies see Adelle Blackett, "Global Governance, Legal Pluralism and the Decentered State: A Labor Law Critique of Codes of Corporate Conduct" (2000-2001) 8 Ind J Global Legal Stud 401. Also on squatter settlements in Brazil, see Boaventura de Sousa Santos, "The Law or the Oppressed: The Construction and Reproduction of Legality in Pasargada” (1977) 12 Law \& Soc'y Rev 5.

86. See Radha D'Souza, "Iaw and Informalisation of Work In India" in Sarath Dhavala, ed, Unprotected Labour in India: Issues and Concerns, (New Delhi: Fredrick Erbert Stiftung, 1995) at 139-68. 
may be extended to other aspects of life in the Third World, including shelter, food, education, and other basic necessities of life. ${ }^{87}$

The celebration of agency in legal pluralism misjudges the cause of creativity, in this case the resilience of informal sector workers and their capacities to create alternative norms to survive. It is the ontological desire for freedom that drives the creativity of the unorganized sector workers. The inability to conceptualize this ontological drive, which is an essential attribute of being human, leads to epistemological confusion over how to understand their creativity and resilience. Legal pluralism's celebration of agency misdirects us from important political questions about the commodification of labour, the modes of its institutionalization in global labour markets, and the way in which human agency might apply its desire for emancipation towards intentional structural transformations beyond existence and survival in the present.

Second, legal pluralism is ideological in that the exclusion of swathes of the economy and society from modern institutions makes state centralization the normative ideal. Third World states must endeavour to bring more and more aspects of the economy and society into their fold, in the same way this happened under Western capitalism. The lending policies of international organizations and Western governments and ideas of good governance promoted by both are premised on the normative ideal of state law and the state's role in introducing regulatory changes compatible with international economy.

Third, legal pluralism as an ideology provides the Third World state with devices to govern and manage the social outcomes of appropriation and expropriation by capitalism and imperialism. It does this by switching between economy and culture as rationale for law-that is, by switching, in Geertz's words, from epochalism to essentialism so as to stave off systemic crisis. ${ }^{88}$

Lastly, it fetishizes the fact that colonialism structurally transformed the Third World and that it is not possible to have capitalist-style social transformation there without the opportunities for colonialism, expansionism, and militarism. Those opportunities have been foreclosed for Third World societies historically.

Legal pluralism was an essential condition for the creation of the colonial state. It was the legal device that brought pre-existing communities tied to land and social groups such as tribes or castes into a relationship with the colonial state

87. See e.g. de Sousa Santos, supra note 85 on squatter settlements in Brazil.

88. For a study of the use of legal pluralism in state policies and its effects on society in Mozambique, see Helene Maria Kyed, "The Politics of Legal Pluralism: State Policies on Legal Pluralism and Their Local Dynamics in Mozambique" (2009) 59 J Legal Pluralism 87. 
and provided them a place within the colonial political economy. ${ }^{89}$ These relationships continue to characterize the Third World and inform international relations, whether they are ethnic conflicts or economic relations. The introduction of personal law, for example, must be evaluated by taking into account the introduction of economic laws, the creation of the colonial state, and the discourses that rationalized the courses of action in economy and culture. Legal pluralists, drawing on sociological and anthropological research, have argued that the introduction of personal law in colonial societies was due to uncertainties of colonial rule and have tended to provide explanations based on the enhanced scope for agency of subordinate social groups. ${ }^{90}$ However, without some conception of Society within which social relationships exist-for example, between men and women or between upper and lower class - the categories used in sociological and anthropological research remain dehistoricized and despatialized. Accordingly, they can either lead to classical modernist universalism or to critical postmodern particularism. Politically, cultural and empirical explanations for personal law produce vacillating orientations to imperialism and colonialism by seeing them as progressive in some respects and oppressive in others: On the one hand, ethno-centric nationalisms that arose after formal decolonization are fetishized; on the other hand, economic subordination by international organizations is represented as an historical inevitability.

Concepts, including sociological and anthropological categories of analysis, are also products of social history and geography. Without a conception of Society in philosophy and social theory, critical scholarship is caught in the hermeneutic loop of either decrying imperialism or qualifying it by alluding to its 'liberating' aspects, and in both cases obfuscating the wider question of the relationship between economy and culture in social theory. The point here is not that legal centralism is superior to legal pluralism or vice versa, or that they can be used in hegemonic ways for imperial agendas and in counter-hegemonic ways by global solidarity movements. Nor is it limited to showing how hegemonic and counter-hegemonic uses share common conceptual grounds that reproduce unequal relations between societies forged under colonialism. Rather, the purpose is to open up pathways for transcending the economy/culture schism internally in Third World societies, on the one hand, and the unequal relations between First and Third World societies externally, on the other. The challenge is to find ways

89. Undoubtedly these changes opened up new possibilities for action for social groups that is captured in the literature on legal pluralism. See e.g. Engle Merry, "Uncertainties," supra note 2 . Arguably, it is necessary to evaluate the new possibilities against emerging structural constraints that new forms of imperialism subsequently introduced in those societies.

90. See also ibid; Engle Merry, "Law and Colonialism," supra note 2. 
of conceptualizing structural autonomy in economic relations between societies and of anchoring politics and culture to the materiality of societies everywhere. In other words, the challenge is to create the conditions in which real diversity can flourish and innovative socio-legal frameworks of analysis can be devised that are capable of sustaining this diversity in everyday life.

\section{CONCLUSION}

There are two impulses that drive the development of law in the Third World. One consists of the economic interests of capitalism; the other of the institutional and social infrastructures necessary for economic actors to operate. In the First World, both of these impulses are internal to the historically constituted societies within which capitalism arose. The dynamics of the social transformation were analyzed in Karl Marx's writings and later in Marxist literature, and inform a rich and diverse critique of capitalist transformation in the First World.9 What Jürgen Habermas refers to as "system" (meaning the economic, legal, institutional, and scientific logics of modern society) and "lifeworld" (which encircles "system" and provides the socio-cultural conditions, including language) both exist in unity as society or, rather, Western societies. ${ }^{92}$ The distinction made by Habermas is an analytical one.

In the Third World, there is a spatial and historical rupture between the economic impulse generated by the production relations in the centres of capitalism and the alien lifeworld in the Third World where the economy must operate without a shared intersubjective order. In other words, there is a spatio-temporal rupture between system and lifeworlds as a result of imperialism: capitalism's expansionist external dimension. This disjuncture characterizes Society in the Third World. Law reifies the disjuncture. This is not the same thing as centre and periphery in World Systems approaches or what David Harvey analyzes as different logics of capital and territory, ${ }^{93}$ but rather it is about differentiating between the internal dimensions of capitalism constituted by subordination of classes within society, and the external dimensions of capitalism constituted by colonialism, expansionism and their subordination of societies qua societies. Class, production, colonial relations, and expansionist governance

91. For the social and legal processes in the transformation of labour as a commodity, see Polanyi, supra note 20. For the constitutive role of law in capitalist relations in society, see Alan Hunt, Explorations in Law and Society: Toward a Constitutive Theory of Law (New York: Routledge, 1993).

92. Supra note 4 .

93. The New Imperialism (Oxford: Oxford University Press, 2003). 
are organized through directionally opposite processes in capitalist-internal and imperialist-external dimensions of capitalist development. The result is two different modes of constitution of societies that produce distinct properties, attributes, features, and internal and external dynamics that we recognize as First and Third Worlds. ${ }^{94}$ Legal concepts and categories are integral to this process. They hold out the key to explanations for the continued reproduction of unequal relations between societies qua societies, a problem at the heart of global justice in the contemporary world.

The national liberation struggles of the twentieth century overestimated political sovereignty and formal legal statehood. The post-independence experience has brought about a deep awareness that structural autonomy cannot be achieved solely through political sovereignty and formal legal statehood. The post-independence period has highlighted the significance of history and geography, capitalism and imperialism, and nature and culture for the problems of the contemporary world. Legal studies, including critical legal studies, tend to take the conceptual vocabulary of law at face value. The result is a philosophical impasse imposed by the epistemologies of Modernism and Enlightenment. It is to this impasse that TWSLS must pay serious attention if it is to remain critically engaged in a transformative social process for freedom and emancipation.

As Zygmunt Bauman argues, postmodernism in philosophy is closely tied to the transformations in the stage of capitalism in the post-World War II era. ${ }^{95}$ The emphasis on culture and context in recent theoretical developments provides valuable tools to deconstruct the philosophical resources that provide capitalism and imperialism with the resilience they have shown. Postcolonialism, as Aijaz Ahmad and others argue, takes its philosophical cues from postmodernism. ${ }^{96}$ TWSLS challenges us to move beyond deconstruction at the empirical and phenomenological levels and to innovate conceptual and philosophical resources that help us transcend the constraints of philosophical liberalism in ways that take freedom and emancipation in philosophy and theory seriously. In legal and social theory, it challenges us to find ways of speaking about global justice and law in the Third World in ways that anchor the Third World to realities at all

94. For the distinctions between colonialism, neo-colonialism, and postcolonialism, see Radha D'Souza, "Colonialism, Neo-Colonialism, Post Colonialism" in Mervyn Hartwig, ed, Dictionary of Critical Realism (New York: Routledge, 2007).

95. Legislators and Interpreters: On Modernity, Post-modernity and Intellectuals (Ithaca: Cornell University Press, 1987).

96. Aijaz Ahmad, "Postcolonial Theory and the 'Post-' Condition" (1997) 33 Socialist Register 353. See also Arif Dirlik, "The Postcolonial Aura: Third World Criticism in the Age of Global Capitalism" (1994) 20 Crit Inquiry 328. 
levels: ontological, structural, and empirical. Philosophical questions cannot be resolved by sociological analysis alone; they must be resolved philosophically. For social theory to attempt to find answers to inequities of colonialism and imperialism within the same level of philosophical consciousness that brought about Modernism, Enlightenment, and capitalism is to abandon the struggle for justice altogether. Equally, if dualism and binary categories dominate Western philosophy, as critical theory is at pains to point out, there is nothing stopping us from looking to other philosophical traditions for answers to the problems of our times.

These reflections on methodology in TWSLS raise questions that quickly transcend Third World issues and call into question assumptions in social theory more generally. The questions raised here are big ones by any reckoning, big enough to warrant a research program to put TWSLS on more solid theoretical foundations. This article has hinted at what such a research program might look like. It is not possible within the space of a single article to develop an alternative methodology. To attempt to provide quick-fix solutions would risk reducing embedded questions with deep roots in social theory to banalities. Besides, the nature of the questions posed in this article call for sustained engagement with the wider scholarly community. Nevertheless, it may be possible to identify a set of methodological sensitivities that TWSLS scholars could be aware of when approaching specific themes or issues about law in Third World societies.

First, it is important to recognize that there is something called Society. Both law and society need to be problematized in TWSLS. Understandings of society must be differentiated at ontological, structural, and empirical levels and accounted for in analyses of concrete problems. The recognition that at the ontological level human life is contingent on Society calls for interrogation of the assumptions of sociological theories about structures, agents, and social transformations. At the empirical level, it calls for investigation of the specific geo-historical conjunctures of the relations between natures, social structures, and peoples that give to particular societies their specific attributes and properties. The questions for TWSLS must therefore encompass properties and attributes of the societies in question as well as the natural and social relations that give to that society its specific attributes and properties. In attempting to do so, disciplinary boundaries, traditions, and vocabularies present problems or render their existence opaque. Greater reflection is called for on the ways in which disciplinary boundaries present a problem in TWSLS.

Second, if concepts develop within and in response to geo-historical processes, how may we recognize this and yet communicate with each other? 
Had I written this article using the language of Jaina or Buddhist philosophy, for example, I could have made the same arguments, though they would have been comprehensible to very few, even in the Third World. The Orientalist critique in the 1960s and 1970s deconstructed the reasons for and ramifications of Orientalism. ${ }^{97}$ It is necessary to move beyond that now. At the empirical level, whatever the historical reasons for it, we have inherited a vocabulary that is in circulation and that is not of our choosing. Nevertheless, the awareness that deconstruction has provided must lead to greater reflection on what is entailed in the use of the vocabulary. Communication is necessarily a social and collective act. Transformations of vocabularies occur only through transformative engagement. In retrospect, did the Enlightenment not change the meanings of society, rights, and so many other terms through sustained engagements with the concepts? If it did, then can a more reflexive TWSLS not transform meanings and vocabulary in more emancipatory ways? For example, in this article I have used terms, phrases, and concepts drawn from Marxist and critical theories to articulate wider concerns about approaches in TWSLS, and in doing I have sought to provide a different inflection on those terms and meanings.

Third, what does it mean to be 'non-dualist' when the world is full of diversity? The challenge here is not to stop at description or indeed presentation of the thesis and the antithesis in any problem, but also, simultaneously, to interrogate the common grounds they share. Such an approach calls for reframing the questions in ways that allow the interrogation of a problem to go beyond dualist framings. The types of answers we get depend, often, on how we frame the question. In the Jaina tradition, for example, a problem is first presented from a range of perceptions that exist about it in the empirical world. The inquiry does not ask which of these is true or false, or which one is better (dualist), but rather it moves on to the next level of reality by asking the non-dualist question, "What must be the nature of reality in this instance if there are all these different perceptions, all of which are true and co-exist?" What is human freedom in the contemporary world, for example, where global solidarity movements critique the use of human rights for imperialist agendas (instrumentalist critique), imperialist institutions use human rights for domination (normative critique), and where both are real and co-exist?

Fourth, postmodern deconstruction has generated recognition of diverse philosophical traditions. For example, it is difficult to envisage any serious scholarly argument today that claims that the Greco-Roman-Christian intellectual tradition

97. Edward Said's works were perhaps the most influential in deconstructing Orientaism. See Edward Said, Orientalism (London: Penguin, 1991); Also see Edward Said, Culture and Imperialism (London:Vintage, 1994). 
is intrinsically superior to all others. This recognition has opened up a rich and varied conceptual repertoire that is widely available to scholars. The challenge is to actually dip into it so as to develop conceptual resources needed for social transformations. It is possible, for example, to argue that while Marxism provides valuable tools for a critique of capitalism, something more is needed to realize the aspirations of a just and egalitarian world-socialism, if that is what we want to call such a world - and further, that we may need to look elsewhere, outside the Western tradition, for conceptual resources to build such a society. Here, Marxism and indigenous traditions both have their value and contributions to make.

The purpose of this article has been a limited one: to open up a sub-field in socio-legal studies by identifying methodological problems in the approaches to TWSLS. The reflections are informed by my practical experiences as an activist lawyer in a Third World context and a legal academic in a First World context. ${ }^{98}$ Whether this call for a new research agenda for TWSLS will be another call in the wilderness or whether it will generate responses from critical scholars, time alone can tell.

98. For more specific examples of the tensions between law in practice and law in theory, see D'Souza, Krishna Waters, supra note 21 at 3-12. 